\title{
ANíbAL BRUNO E A REFORMA PENAL (*)
}

PROF. ALCIDES MUNHOZ NETTO

\section{INTRODUÇÃO}

1. Participo, com satisfação, desta série de conferências em homenagem a Aníbal Bruno. É uma grata oportunidade de, uma vez mais, externar a grande admiração e respeito que sempre devote ao insígne mestre. Sua notável obra assinala decisiva etapa na evolução da moderna literatura jurídico-penal em nosso país. Ninguém, antes dele, havia, no Brasil, versado temas penais, com o sistema, a profundidade e o rigor científico que caracterizam os seus escritos. Confesso-me seu discípulo, entre tantos outros em quem seu trabalho despertou ou estimulou a vocação para o Direito Penal. Aníbal Bruno fez, realmente, do magistério superior o seu destino, como sempre pretendeu. (Nilo Batista, O Mestre Aníbal Bruno, in Ciência Penal, vol. I, pág. 5, 2. a série). Se mais não produziu, foi porque a nação para isso não the deu meios materiais. Trago, a respeito, testemunho pessoal. À instâncias minhas, o Prof. Everardo Luna, em 1968, levou-me a conhecê-lo. Encontramos Anibal Bruno em modestíssimo apartamento, no Rio de Janeiro. De há muito aposentado, vivia dos minguados proventos de catedrático e dos parcos direitos autorais, destinados, no Brasil, a livros científicos. Conversamos longamente. Era uma satisfação usufruir de seus conceitos precisos acerca de filosofia, literatura, política e direito. IndagueiIhe, a certa altura, sobre a conclusão de seu Tratado de Direito Penal. De seus lábios ouvi, entre pesaroso e estarrecido, que a sua honestidade científica o impedia de ultimar o livro. Por nunca ter se deixado seduzir por ambições econômicas, desprezando a advocacia e outros encargos que o desviassem da pesquisa e do estudo, Anibal Bruno confessava-se sem recursos para adquirir as novas edições de autores estrangeiros, que não mais poderia continuar citando, ante o risco de haverem modificado suas originárias concepções.

(*) Conferência proferida em Belo Horizonte, em 11.11.76. 
Promessas de subvenções oficiais the tinham sido feitas, mas delas já descria o mestre. Mal posso acreditar, ainda hoje, exista, em nosso país, tamanho descaso por homens de pensamento do quilate de Aníbal Bruno, que, dos poderes púbicos, teria de receber todas as condições, à continuidade da inestimável contribuição ao progresso das letras jurídicas brasileiras.

\section{DOGMÁTICA E POLÍTICA CRIMINAL}

2. Nada mais adequado, num preito de gratidão e de saudade ao inesquecível penalista pernambucano, do que focalizar-lhe a atualidade do pensamento. E, numa época em que se cogita da reforma de nossas instituições penais, parece oportuno proceder o confronto das idéias de Aníbal Bruno acerca do direito constituendo, com as atuais tendências de aperfeiçoamento do direito punitivo.

Na primeira edição, de seu Direito Penal, escrito "com o pensamento voltado para os jovens esíudiosos" (ed. de 1956, tomo I, Prefácio), Anibal Bruno destacava a importância da crítica e da política criminal, incluindo-as na própria ciência penal. A posição dạ política criminal - afirma tiva - "é sempre adiante do Direiło vigente, cujas reformas oporłunas sugere e orienta, recebendo inspiração, por um lado, da filosofia e da hisłória, e por outro, e sobrełudo, das ciências eriminológicas. Embora distinta do Direito Penal, penetra nele intimamenie através da crítica, fornecendo a ela os mais importantes subsídios... A maioria dos dogmáticos refutariam essa posição da crírica dentro da ciência do Direito Penal. Mas e ela que concilia como vimos, o rigor da técnica com o sentido das fôrças empíricas que movem o fenômeno do crime, e, sem deformar o Direilo como ele realmente existe, esíabelece uma relação entre o presente e o futuro, úîil à compreensão, que poderíamos chamar evolutiva, do Direiło vigente e hoje mais do que nunca justificada, quando os códigos penais, com as concessões que têm feito às exigências fundamentais da corrente de inspiração naturaiisła, revelaram que o Direifo Penal está dentro de uma renovação profunda nesse sentido. E assim ela eviła o perigo maior do tecnicismo, que é fazer perder ao jurista o sentido do hisłórico, cerrando - Direito vigente como coisa acabada e entorpecendo-lhe o movimento para a sua evolução e transformações oportunas, o que nos levaria, por fim, por caminhos diversos, à idéia de um código ideal, perpetuamente válido, contra a qual valeria renovar o batalha que Savigny conduziu atłravés do hisłoricismo" (ob. cit., tomo I, págs. 41, nota 19, e 47). 
Esta inclusão da Política Criminal na ciência penal que Aníbal Bruno defendeu na década de 50, está hoje em voga na Alemanha. Com efeito, Claus Roxin, catedrático na Universidade de Munique, e um dos mais acatados penalistas germânicos da nova geração, defende idéias semelhantes. Procurando dar novos rumos à dogmática jurídico-penal, em crise ante a polêmica entre finalistas e causalistas, procalma Roxin que as soluções penais devem ser conjugadas com a polâítica criminal, sem abandono da função do ordenamento jurídico de "assegurar a igualdade na aplicação do Direito e a liberdade individual, frente ao ataque do "Leviathan" do Estado (Política Criminal y Sistema del Derecho Penal, Munich, (1972).

Pensa Roxino que as concretas categorias do delito-tipicidade, antijuridicidade e culpabilidade - devem se sistemazar, se desenvolver e se completar sob o prisma de sua função político-criminal (ob. cit. pág. 40).

Assim, em relação à tipicidade, para uma interpretação restritiva que atualize a sua função de magna carta do Direito Penal e sua natureza fragmentária, deve-se recorrer, como critérios auxiliares, a princípios como o da adequação social, que restringe o teor literal do tipo, pelo acolhimento de formas de conduta socialmente admissíveis e ao princípio da insignificância, que permite, na maioria dos tipos, excluir danos de pequena monta. Maus tratos, desta forma, não seriam quaisquer danos à integridade corporal, mas só aqueles relevantes, da mesma forma que a difamação só seria a lesão grave à pretensão social de respeito (ob. cit. pág. 53).

No que toca à antijuridicidade, para estabelecer o âmbito das causas de justificação, alcançando-se, em consequência, uma correta solução social dos conflitos, tem de se jogar, alternativamente, com os princípios da prevalência do direito, da auto-proteção, da proporcionalidade, da ponderação dos bens e da autonomia. Na legítima defesa, por exemplo, os princípios de auto-proeção e de prevalência do direito são os que servem de base à sua regulamentação legal. Isto significa que todo $\circ$ mundo tem - direito a defender-se de ataques proibidos, de maneira a que não sofra nenhum dano. Ainda que possível ao agredido subtrair-se ao ataque, a legítima defesa é permitida. O princípio da prevalência do direito (a idéia, portanto, de que o direito não tem que ceder ante $o$ injusto) vai mais longe aqui que os interesses de auto-proteção... A auto-proteção e a prevalência encontram, porém, seus limites comuns num princípio, reitor de todo o ordenamento jurídico, o princípio da proporcionalidade, que conduz à renúncia da legítima defesa, nos casos de absoluta desproporciona- 
lidade dos bens que estão em conflito (isto é, nos casos em que se infringem lesões corporais graves para se defender de danos de pequena importância). Ademais, do ponto de vista político criminal, - princípio da prevalência do direito não pode viger para as agressões de crianças e enfêrmos mentais, porque o ordenamento jurídico não necessita impor-se a pessoas que não podem se motivar pelas normas que infringem e que, precisamente por isto, ficam impunes (ob. cit. págs. 57 a 60 ).

Quanto à culpabilidade, deve a mesma ser relacionada, de um ponto de vista político-criminal, com a teoria dos fins da pena. Neste sentido, cumpre indagar se o autor da ação típica e antijurídica merece ou não ser punido, isto é, se a pena, no caso, se faz necessária, seja para castigar o mal praticado (retribuição), seja para intimidar terceiros e evitar que pratiquem ações análogas (prevenção geral), seja para corrigir o próprio autor (prevenção especial). Com este critério, através da culpabilidade, limita-se a incidência da pena. Com efeito, se, verbi gratia, alguém - por qualquer razão que seja não pode evitar o injusto típico que praticou, não há fundamento para puní-lo: qualquer que seja a teoria da pena adotada, não se pode querer retribuir uma culpabilidade inexistente, nem afastar a generalidade das pessoas da causação de consequências inevitáveis, nem é necessário um efeito de prevenção especial, a quem não se pode censurar a conduta (ob. cit. pág. 67).

\section{A TRILOGIA DAS REFORMAS PENAIS}

3. Correspondem às atuais tendências evolutivas do Direito Penal, as idéias de não incriminar infrações insignificantes, de evitar a incidência de penas, sobretudo as privativas de liberdade, se desnecessárias à retribuição e à prevenção e de emprestar à culpabilidade função de garantia individual, erigindo-a em indeclinável pressuposto das sanções criminais.

Com efeito, atualmente, todo o movimento de renovação legislativa, no campo punitivo, procura dar efetividade à triologia: descriminalização, despenalização e limitação da responsabilidade penal pela culpabilidade.

Pois bem, destes anseios, hoje gerais, já compartilhava o nosso Aníbal Bruno, há vinte anos passados. Era ele, na verdade, adepto da idéia de excluir do direito punitivo as infrações de bagatela, que só sobrecarregam os juízos criminais e comprometem a dignidade do magistério punitivo. Também preconizava evitar-se as penas privativas de liberdade, substituindo-as por outras providências ju- 
rídico-penais. E ao princípio da nulla poena sine culpa, Aníbal Bruno emprestara importância fundamental.

Acerca da descriminalização, escrevia o grande penalista pátrio: "a pena é um recurso extremo de que se vale o legislador, quando de outro modo não the seria possível e assegurar a manutenção da ordem jurídica (ob. cit., tomo I, pág. 286)... Na evolução das legislações, algumas figuras penais podem perder esse caráter, como tende a ocorrer hoje com o adultério, por exemplo". (ob. cit., tomo IV, pág. 29).

Era incisivo o pronunciamento de Aníbal Bruno sobre a despepenalização: "Tem-se revelado uma crise na pena privativa da liberdade, reclamando-se uma redução ao mínimo dessa privação, falando-se em prisão sem muros ou mesmo em trabalho livre obrigatório para substiłuíla, a fim de evitar ao condenado restrições que embaracem o seu ajustamento à vida normal na comunidade de Direito. Esta é a mais grave das crises que têm afetado a pena, a que a atinge nas suas características tradicionais de retribuição e afiição que se torna evidente é que a Penologia atual, inspirada na decisão de reajustar o déelinquente à vida social dentro do Direito, se encaminha cada vez mais para restringir a privação da iberdade ao mínimo, substituindo-a por um regime que realize ou imite as condições da existência livre. Porque realmente se trata é de criar no delinquente o hábito de reagir conforme ao Direito, em meio às provocações e estímulos malsãos que a vida em sociedade oferece, mas um hábito para o qual concorra a vontade do próprio criminoso, não uma rotina superficial imposta pelas condições do modo de viver na prisão e que só aí teria eficácia".

Condenava, também, as penas curtas de prisão, nas quais "não é possível exercer sôbre o delinquente nenhuma ação contínua e duradoura capaz de modificar a sua personalidade, corrigindo a deformação criminógena que nela se manifestou. Ao contrário, o criminoso, muiłas vezes primário, vai reunir-se na prisão a outros criminosos, que afinal se corrompem mùtuamente, cada qual com a sua própria experiência do crime, a vaidade das suas façanhas e os pro. jetos de novos extravios. A sugestão do ambiente é para fortalecer a perseverança no caminho do delito e aperfeiçoar a técnica do delinqüente." (ob. cit., tomo III, págs. 23 , nota 2, 65, nota 9, e 66).

À função limitativa da culpabilidade, o mestre pernambucano emprestava a maior ênfase, fruto, naturalmente, de sua liberal concepção acerca do direito punitivo. "O Direito Penal, é um sistema jurídico de dupla face, que protege a sociedade contra a agressão 
do indivíduo e protege o indivíduo contra os possíveis excessos de poder da sociedade na prevenção e repressão dos fałos puníveis. Tôda a sua ałuação se faz sob o critério regulador da justiça... A lei punitiva, não só promove a defesa social pela prớeção que confere, por meio dos rigores da sua sanção, às condições exisłenciais da sociedade, nos têrmos em que ela se acha constituída, mas assegura e delimiła o campo de ação do Estado na repressão e prevenção direta da delinqüência, e com essa delimiłação garante as liberdades individuais em geral e os direitos fundamentais que subsistema no próprio delinqüente" (ob. cit., tomo I, págs. 32 e 199). Especificamente sobre o princípio do nulla poena sine cuipa, que considerava "imperiosa exigência da consciência jurídica", asseverava: "O Direiio Penal de hoje é conceitualmente um Direito Penal da culpabilidade. M. E. Mayer pôde dizer que a dignidade do Direito Penal reside na reprovação da responsabilidade pelo resultado e no reconhecimento da responsabilidade pela cuipabilidade... Persistem, entretanto, nas legislações vigentes, casos em que se faz sentir 0 pensamento da responsabilidade pelo resultado, o que mostra que a evolução do princípio ainda não se encerrou. Esses resíduos das velhas concepções objetivas, que existem mesmo nos códigos mais modernos, como o nosso, mostram-se, sobrefudo nos chamados crimes qualificados pelo resultado, fatos puníveis em que se exacerba a pena quando neles se produz invoiuntariamente um resultado mais grave, casos que von Liszł diz muito bem que não correspondem nem à consciência jurídica de hoje, nem aos princípios de uma política criminal racional" (ob. cit., tomo II, págs. 407 e 410, nota 1).

4. Demonstrada, ainda que suscintamente, a atualidade do pensamento de Aníbal Bruno, cumpre, numa segunda parte deste trabalho, examinar a utilidade das idéias enunciadas e, em balanço panorâmico, verificar quais os seus reflexos no Código Penal brasileiro de 1969.

\section{DESCRIMINALIZAÇÃO}

5. Descriminalizar significa colocar determinado comportamento fora do sistema punitivo. Isto não implica, necessariamente, em proclamar a licitude das condutas postas à margem da repressão penal. Traduz, também, o entendimento de que certos ilícitos jurídicos, definidos como infrações penais, podem ser mais racionalmente conjurados com sanções de outra natureza (administrativas, civis ou tributárias), ou com medidas meramente preventivas.

O Estado, ao estabelecer os crimes e contravenções, tem de se ater a certos limites. Por um lado, restringe-lhe a atuação a própria 
filosofia sob a qual se organizou, pois "iodo sistema de Direito assenta em bases filosóficas" (A. Bruno, ob. cit., tomo l, pág. 45). Ora, a filosofia ocidental rejeita o Estado totalitário, propondo-se dar efetividade às declarações universais de direito, que garantem certas liberdades individuais, como a liberdade de consciência. Por outro lado, na seleção dos fatos a serem considerados crimes. o legislador, até por questão de economia, deve partir sempre do princípio de que o Direito Penal "só deve intervir como ultima ratio da política social. "É o que, invocando W. Maihofer, proclama Jorge de Figueiredo Dias: importa que o legislador tome verdadeiramente a sério a imposição de só colocar sob ameaças de pena aquelas condutas que impedem ou pôem em perigo, de forma intolerável, a livre realização da personalidade ética do homem na comunidade em que vive". (A Reforma do Direito Penal Português, pág. 39, Coimbra, 1972).

Infelizmente, entretanto, nas últimas décadas, o legislador não tem sabido resistir ao que o mesmo penalista denomina de "sedução de uma tão inconveniente como perigosa inflação incriminał6ria" (ob. e loc. cits.). Fatos de escassa importância, através de impresionante sucessão de leis, vêm sendo erigidos à categoria de infrações penais, por meras razões de conveniência momentânea. A pretexto de regular novas relações, decorrentes do próprio desenvolmento e da civiizlação, ou de sofrear abusos, o stado crla, incessantemente, novos tipos penais. É que lhe é mais fácil e barato criminalizar do que prevenir. Custa muito menos, por exemplo, transformar infrações de trânsito em ilícitos penais, através de leis que nem necessitam conter a especificação de recursos orçamentários, do que construir obras de engenharia de tráfego, capazes de atenuar os riscos da circulação de veículos.

Paralelamente a este fenômeno, conservam os velhos Códigos figuras penais anacrônicas, fundadas em concepções morais utrapassadas ou em fatos que a consciência social deixou de considerar criminosos. Nascidas de exigências de determinado momento da cultura, certas normas penais revestem-se daquela precariedade a que aludia Anibal Bruno, "sobretudo nos períodos históricos de crises social e política, como o que hoje vivemos. A consciência desse caráter provisional é o que se faz sentir nas recentes criaçöes legislativas penais" (ob. cit., tomo IV, pág. 30, nota).

Na verdade, a hipertrofia da legislação penal criou a necessidade de uma "tarefa de purificação do autêntico Direito Penal", que The restaure a dignidade e a eficiência. A descriminalização, assim, apresenta-se como necessidade inadiável, sentida em todos os quadrantes. Entre nós, a Sociedade Brasileira de Criminologia, aprecian- 
do o novo Código Penal e o projeto de Código de Processo Penal, fez notar que a crise da Justiça brasileira tem como causa preponderante o grande número de processos sobre fatos sem importância, que nossos juízes são obrigados a apreciar. O relatório de Evandro Lins e Silva, aprovado pela entidade, consigna: "questóes patrimoniais e criminais inteiramente irrelevantes, quer sob o aspecto jurídico, quer sob o prisma social ou econômico, convocam a atenção de ministros, desembargadores e juízes para decidí-las, exigindo, até o julgamento, uma organização burocrática dispendiosa e um papelório inteiramente dispensável. Contravenções e oưtras infrações levíssimas, cobranças irrisórias, assuntos de nonada constiłuem a massa de serviço dos iúzizes e tribunais do país. A máquina judiciária é emperrada e não caminha e até se decidir um processo banalíssimo decorrem muitos meses e não raro muitos anos de andamento e de espera, nas prateleiras dos cartórios, nos escritórios dos advogados e nas casas dos juízes. Isso, evidentemente, está errado e carecendo de uma reforma de fundo, especialmente nos grandes centros, onde um juiz recebe centenas e às vezes mais de mil processos por ano, devendo instruí-los e juígá-los. De ano para ano os autos se vão amontoando sem ser possível dirimir, com razoável presteza, as causas submetidas ao Poder Judiciário. Para manter em dia - serviço de uma Vara é preciso um esforço inaudito. $O$ juiz despacha o expediente, que não é pequeno, ouve várias testemunhas, interroga acusados, atende as parłes, fiscaliza o cartório, preside os debates das audiências de julgamento e ainda tem de proferir uma ou duas sentenças por dia. A crise da Justiça está fundamentalmente na sua base, no atraso com que são jugados os feitos, pela impossibilidade em que se vêem os juízes de dar solução à mole imensa de casos grandes e insignificantes - que lhe são distribuídos sem cessar, como uma espécie de motu continuo. Isło acarreta desprestígio para o própria Justiça perante a opinião pública, insuficientemente informada desses percalços e estorvos. Espaíha-se uma desconfiança generalizada no aparelho judiciário, que não tem condições de reparar, com prontiidão e eficácia, a vióiação dos direiłos dos membros da comunidade." (Sobre a Reformar dos Códigos in Jornal do Brasil, ed. 21.09.75, pág. 20, 2. ${ }^{\circ}$ caderno).

6. Se é fácil perceber a utilidade em reagir à hipertrofia da lei penal, através da descriminalização, mais delicada é a tarefa de escolha dos ilícitos penais a serem abolidos. Os conclaves de Direito Penal e de Criminologia, internacionais ou locais, como o IX Congresso Internacional de Direito Penal, Haia, 1964, (R.B.C.D.P., n. ${ }^{\circ}$, págs. 124 a 126) e o Seminário de Direito Penal e Processo Penal de Belo Horizonte, 1974, (R.D.P., n. ${ }^{\circ} 15 / 16$, pág. 92), entre 
outros, fornecem subsídios à descriminalização, indicando as figuras ou as categorias de delitos a serem suprimidos.

Certamente com base em dados de tal natureza, foi que L.H.C. Hulsman apontou os setores a descriminalizar (Descriminalização, in R.D.P. n. ${ }^{\circ}$ (10, págs. 7 a 26). Tais setores são: 1) as infrações fundadas exclusivamente na preocupação de fornar dominanłes certas concepções morais, como, por exemplo, a blasfêmia, o adultério, incesto, a sodomia, o homossexualismo ou a prostituição sem envolvimento de menores e sem escândalo público e certas espécies de delitos decorrentes de intolerância política. Trata-se de infrações sem graves danos sociais, que não ofendem bens ou interesses de outros membros da comunidade, traduzindo, antes, o desejo da maioria, ou dos detentores do poder, de impor coativamente suas idéias aos dissidentes, prática incompatível com sistemas de liberdade. Nas autênticas democracias, há que se respeitar o direito das minorias de terem concepções divergentes, em matéria de moral, de política ou de comportamento sexual. Como salienta Jorge de Figueiredo Dias: "o Direito Penal está aí para prołeger inłeresses socialmente relevantes, bens jurídicos, e de nenhum modo para impor qualquer concepção moral em sentido estriło" (ob. cit., pág. 40); 2) as infrações inspiradas pelo desejo de ajudar o delinqüente, como o uso de drogas, - alcoolismo, a mendicância e a vadiagem. O tratamento compulsório é comprovadamente ineficaz, ainda mais quando se pretenda realizá-lo através da pena, estigmatizante e de duvidoso valor recuperativo. Melhores são as medidas de assistência, que despertem nos destinatários o desejo de regenerar-se e a conseqüente colaboração a este objetivo; 3 ) as infrações em relação às quais a ameaça penal comprovadamente não funciona. Em si, a eficácia intimidativa da pena está hoje em franco descrédito. No último Congresso da Associação Internacional de Direito Penal, Budapest, 1974, foi aprovado o relatório Kirali, consignando ser altamente improvável a prevenção geral através da pena (R.D.P., n. ${ }^{\circ} 15 / 16$, págs. 81/82). Com maior razão o duvidoso efeito intimidatório das sanções penais não existirá quanto às infrações socialmente toleradas, como casa de prostituição, certas modalidades de aborto e o nosso brasileiríssimo jogo do bicho; 4) as infrações de bagatela, como muitas das contravenções penais, que melhor se situariam como meros ilícitos administrativos. Pitorescamente, observou Nilo Batista o paradoxo a que, no Brasil, pode conduzir um simples desrespeito a sinal de trânsito: "por avançar um sinal, dirigindo seu veículo, qualquer cidadão será sumariamente muitado pelo guarda de trânsito, em importância considerável, que pode alcançar meio salário mínimo; pela contravenção de direção perigosa, que consiste em dirigir veículos pondo em risco a se- 
gurança alheia (art. 34, L C P ), será mobilizada uma delegacia de polícia (delegado, escrivão, agentes), ouvidas testemunhas, formalizado um procedimento, acionado um tribunal (juiz, promotor, advogado, escrivão, oficial de justiça), com audiências e prazos, para afinal ser o cidadão condenado à multa de $\mathrm{Cr} \$ 2,00$. Aquele que supusesse corrigir $\bullet$ absurdo dessa sentença elevando a pena pecuniária cominada à contravenção, é, seguramente, um amante dos caminhos tortuoscs" (Algumas Palavras Sobre Descriminalização, in R.D.P., vol. 13/14, pág. 38) Aliás, em matéria de ilícitos de trânsito, é sensível a tendência de não abusar da incriminação. Os países que as criminalizaram em excesso estão retrocedendo, como se verificou nas II Jornadas Latino-Americanas de Defesa Social, Brasilia, 1975.

7. No Brasil, há evidente excesso de incriminação. Além das figuras típicas do Código e da Lei de Contravenções Penais em vigor, existem as definidas em abundante legislação complementar. Consoante Reale Junior, a tipificação surge como "recurso para que - direiło valha enquanto ordena sob ameaça penal e não como via extrema para a tutela de valores, cuja positividade deva ser necessariamenè respeitada". (Descriminalização, in Revista do Instituto dos Advogados Brasileiros, n. ${ }^{\circ} 29$, pág. 189).

Mais de cinco dezenas de leis extravagantes, consideram ilícitos penais violações jurídicas insignificantes ou fatos que só afetam interesses secundários da administração pública. Assim é que se incrimina: produzir açúcar acima da quota autorizada (Dec. Lei 16/66); vender sob o nome de couro produtos que não sejam obtidos da pele animal (Lei n. ${ }^{\circ} 4.888 / 65$ ); paralisar o incorporador de edificação em condomínio a obra por mais de 30 dias (Lei n. ${ }^{\circ} 4.591 / 64$ ); deixar de restituir à autoridade licenças extintas pelo decurso do prazo (Lei $n .^{\circ}$ 4.771/65); atuar como instituição financeira sem autorização do Banco Central (Lei n. $\left.{ }^{\circ} 4.595 / 64\right)$; instalar ou utilizar estação ou apareIho rádio-elétrico sem observância de disposição legal (Código de Comunicações)) e, até, pescar sem autorização da SUDEPE (Dec. Lei .... $221 / 67)$.

Ao legislador de 1969 oferecia-se o ensejo de corrigir estas demasias, bem como o de abolir tipos anacrônicos, universalmente ultrapassados. O novo Código, entretanto, nem só manteve toda a legislação sobre crimes especiais (art. 401), como conservou e aumentou o elenco de fatos cuja incriminação não mais se justifica.

Quanto aos delitos fundados em meras concepções morais, manteve-se a incriminação do adultério (art. 264) e da casa de prostituição (art. 252), acrescentando-se-lhes os delitos de incesto (art. 258), 
ressuscitado das Ordenações do Reino, e de inseminação artificial (art. 267), de objetividade jurídica truncada e tratamento absurdamente mais grave do que o de adultério (é inexplicável que o delito haja sido incluído entre os crimes contra o estado de filiação, quando se trata de ofensa ao casamento, tanto que não subsiste se o marido consente na inseminação. Nem faz sentido que a pena e as condições de procedibilidade sejam mais desfavoráveis que as do adultério, único crime configurável em caso de inseminação, fora do casamento, por meio natural).

Apesar da reconhecida ineficácia da ameaça penal quanto a certas modalidades de aborto, ampliou-se sua incriminação, suprimindo-se a impunidade do aborto sentimental (art. 129), providência inexplicável num diploma que cria, como modalidade privilegiada, o aborto por motivo de honra (art. 127), com pena passível de suspensão condicional (art. 70).

No que concerne aos delitos de bagatela, conservou-se figuras como a hospedagem fraudulenta (art. 188), os crimes contra as marcas de indústria e comércio e de concorrência desleal (Título III, capítulos III, IV e V), e outros tipos destituídos de dignidade penal.

Foram abolidos, apenas, os delitos de perigo do contágio venéreo e de moléstia grave, em face do desenvolvimento dos antibióticos bem como da "ausência de repercussão forense dos fatos porvenîura havidos" (Exposição de Motivos, n. ${ }^{\circ} 45$ ) e o atestado contra a liberdade de associação sindical (C.P. 40, art. 199).

Assim, a nossa reforma penal, em lugar de descriminalizar, realizará autêntica e lamentável criminalização.

\section{DESPENALIZAÇÃO}

Despenalizar é excluir ou reduzir a incidência das penas privativas de liberdade. Por ser mais amplo que a idéia que exprime, o termo tem de ser compreendido sensu stricto.

Já constitui truísmo afirmar a crise da pena de prisão. No século XIX, acreditava-se em sua eficácia ressocializadora; hoje é ela encarada como fator criminógeno. Trata-se do resultado natural da evolução da penologia: da mesma forma que as penas corporais, cruéis e infamantes cederam passo para as penas privativas de liberdade, estas, agora, devem dar vez a outras sanções, patrimoniais, ou restritivas de liberdade. A prisão há de constituir o recurso extremo, a última solução, enquanto não se elaborar, para substituíla, um sistema penal coerente, conforme recomendações do IX Congresso Internacional de Direito Penal (R.D.P., n. $15 / 16$, pág. 82). 
O problema das penas privativas de liberdade agrava-se nos países em desenvolvimento. Preocupados com as suas necessidades básicas, de cuja solução depende o próprio progresso, não podem estes destinar recursos suficintes à construção ou à ampliação de estabelecimentos penais. No Brasil, as nossas prisões são notoriamente insuficientes para abrigar os condenados. Em São Paulo há $70 \mathrm{mil}$ e, no Rio de Janeiro, 50 mil mandados de prisão aguardando cumprimento, por falta de capacidade dos estabelecimentos penais. A construção de novas penitenciárias e a manutenção das existentes representam pesados ônus sociais. Cálculos do início do ano passado, revelam que a construção de novos presídios com capacidade para mil detentos, custava 170 milhões de cruzeiros, ou seja, 170 mil cruzeiros para cada internado. De outra parte, os gastos operacionais eram de 4 mil cruzeiros, por mês, para cada preso.

Para atenuar estas dificuldades é útil restringir a incidência das penas privativas de liberdade, criando-se outras espécies de sanções e aumentando-se os poderes discricionários dos juízes, para que tenham maior amplitude na substituição de penas de prisão por outras mais leves, na concessão do sursis e do perdão judicial e no encerramento antecipado de processos, por infrações pequenas, de agentes primários, não perigosos, que hajam reparado o dano decorrente do delito. A despenalização, nestes termos, preconizada em vários conclaves de penalistas brasileiros, como o Seminário de Direito Penal e Criminologia de Goiânia, 1.973 (v. Moção de Goiânia, R.D.P., N. 9/10, pág. 61), Seminário de Direito e Processo Penal de Belo Horizonte, 1974, V Congresso Nacional de Direito Penal, São Paulo, 1975 (S.D.P., n. 15/16, pág. 91), é também reclamada pelo nosso poder judiciário. Em seu relatório diagnóstico, o Supremo Tribunal acentuou "a inadeqüação do sistema de penas, com a preponderante idéia de encarceramento, ainda que nenhuma a periculosidade do réu. A multipicidade de condenações à prisão, não executadas pela impossibilidade material de se efetivarem, dá margem à argüições de ineficiência do sistema carcerário e de desvio de deveres funcionais. A faculdade de se substituírem penas detentivas por sanções pecuniárias adeqüadas, ou por medidas reeducativas; e a extensão da "prisão albergue", a par de outras sugestões, contribuiriam para a melhoria da Justiça Penal"

9. Embora timidamente, o legislador penal de 1969 realizou certa despenalização, além de ter posto fim, praticamente, à dualidade das penas privativas. A reclusão e a detenção, dispõe o novo Código, devem ser executadas de modo a que exerçam sobre - condenado individualizada ação educativa, no sentido de sua re- 
cuperação social (art. 37). O sistema do Código de 40, quanto a diversidade na forma de executar as penas de reclusão e de detenção, além de impraticável, contraria o ideal de ressocialização. Na correta observação de Anibal Bruno, "as penas detentivas são proporcionadas ao deliło praticado mais pela sua quantidade do que pela sua qualidade (ob. cit., tomo III, pág. 63). A.penas para efeitos processuais, podem ser conservadas as duas categorias de privação de liberdade, facultada, em certas hipóteses, a substituição da reclusão por detenção (art. 73, § $3 .^{\circ}$ ).

As criticadas penas de curta duração insuficientes para ressocializar, mas suficientes para corromper, foram evitadas no diploma de 1969. Na verdade, permitiu-se a substituição da detenção inferior a seis meses pela pena de multa (art. 46), estendeu-se o sursis à pena de reclusão (art. 70), inovação que, segundo Heleno C. Fragoso, é bastante para justificar a vigência do novo Código. Ademais, previu-se o estabelecimento penal aberto e institucionalizou-se a prisão albergue, para os criminosos primários, de nenhuma ou escassa periculosidade. A prisão aberta será destinada aos condenados a até seis anos de reclusão ou oito de detenção, podendo constituir fase da execução de penas mais graves. A prisão albergue será aplicada como providência única, em condenações não superiores a três anos, ou como etapa do cumprimento da pena superior a esse limite (art. 40). Também foram ampliadas as hipóteses de perdão judicial, previsto, por exemplo, para lesões leves, recíprocas ou privilegiadas (art. 131, § 5.॰), para o dano com reparação de prejuízo (art. 178), para o furto ou apropriação de coisa fungível comum, não excedente ao quinhão do condômino (arts. 166 e 181, § 2..$^{\circ}$ ), para a receptação da coisa de pequeno valor ou restituída antes do início da ação penal (art. 196, parágrafo único) e para a destruição de petrechos de fasificação de moedas (art. 322, parágrafo único).

Sob outro aspecto, procurou-se limitar as penas de grande duração, igualmente inconvenientes. Consoante assinala Jorge de Figueiredo Dias, cuidadosa investigação criminológica revela "que um tempo de prisão superior a dez ou quinze anos impossibilita radicalmente, salvo em casos especialíssimos e atípicos, qualquer tentativa lograda de ressocialização: quem passa mais que aquele tempo no ambiente artificial da prisão perde a possibilidade de se orientar na sociedade em que seja reintroduzido, para além do que sofrerá provaveímente distúrbios psíquicos irrecuperáveis; uma pena de prisão superior tornar-se-á pois, do ponto de vsiła da recuperação social, algo de muito parecido com a pena de morte" (ob. cit., pág. 35). A limitação da duração máxima das penas privativas de liberdade rea- 
liza-se no novo Código: a) pela manutenção dos limties máximos da detenção e da reclusão em 10 e 30 anos (art. 37, § $1 .^{\circ}$ ), rejeitado assim o critério do Anteprojeto Hungria de elevá-os para 20 e 40 anos (art. $\left.35, \S 10^{\circ}\right)$, e, b) pela preservação do livramento condicional, possível depois de cumprida certa parte da pena, qualquer que seja a sua natureza ou quantidade (art. 74).

Vê-se, dest'arte, que, em matéria de despenalização, o legislador de 1969 foi sensível às modernas tendências. Pecou, contudo, pelo excesso de timidez, pois poderia ter inovado mais, quer com a previsão de outras espécies de sanção penal, quer com a ampliação dos casos de sursis, de substituição da privação de liberdade por multas e de perdão judicial.

\section{LIMITAÇÃO DA RESPONSABILIDADE PELA CULPA}

10. Culpabiildade é o juízo de censura pessoal, incidente sobre o autor da conduta típica e ilícita. Compõe-na a imputabilidade, a possibilidade do conhecimento do ilícito (potencial consciência da antijuridicidade) e a exigibilidade de comportamento conforme ao direito (cfr. Heleno C. Fragoso, Lições de Direito Penal - Parte Geral, pág. 213). A reprovabilidade penal assenta-se, realmente, na capacidade e na possibilidade de agir o autor de acordo com os imperativos jurídico-penais, ou seja, num poder formar sua resolução em consonância com a norma.

Diz-se que, assim concebida, a idéia de culpabilidade está enfraquecida, porque este poder agir de outra forma é uma premissa indemonstrada e indemonstrável (cfr. Claus Roxin, A Culpabilidade Como Critério Limitativo da Pena, in R.D.P., n. ${ }^{\circ} 11 / 12$, pág. 7). Mas, da mesma maneira que a controvérsia entre determinismo e livre arbítrio permanece insolúvel, cientificamente, não há, também, como comprovar inexista, no ser imputável, em condições normais, a faculdade de resistir a impulsos criminosos. Pois bem, e esta faculdade de resistência que, ao mesmo tempo, fundamenta a culpabilidade e limita a responsabilidade penal. Não se ignora que o Direito tem a preponderante função de proteger bens e valores fundamentais da comunidade social e, portanto, de tutelar interesses socialmente reevalntes. Mas é preciso reafirmar, com Figueiredo Dias, "que nem por isso se furta ao princípio da culpa plena capacidade para resistir aos ałaques que são dirigidos do exterior, isto é, em nome de um Direito Penal defensivo, de mera intimidação, que relega a pessoa humana para objẹto de fins heterônomos (ficando assim aberto o caminho para um Direito Penal de puro "terror") ou de um Direito Penal de cariz exclusivamente protetivo que, invocando um sa- 
lutar humanismo, forna a pessoa em objeto de medidas terapêuticas coercivas e sob a capa do "verdadeiro bem do delinqüente" viola sua autonomia ética e possibilisa a sua entrega ao Estado todopodieroso" (ob. cit., pág. 15).

Verdadeiramente, a culpabilidade tem uma função política que excede à sua importância conceitual: ela limita o poder punitivo do Estado, pela exigência de que a pena só incida se o autor, além de ter praticado o ilícito típico, seja passível de censura pessoal.

O princípio do nulla poena sine culpa constitui-se, pois, numa garantia da liberdade individual. Tal garantia é necessária à realização da própria Justiça, posto que o dogma do "nullun crimen, nulla poena sine proevia lege, "†ão caro aos sistemas punitivos liberais, nem sempre assegura os direitos individuais. É que o princípio da anterioridade da lei penal perde muito de sua eficácia em face dos tipos desconhecidos e dos tipos penais abertos. De pouco vale a norma de que não há crime sem lei anterior que o defina, quando a sucessão de leis incriminatórias (supra n. ${ }^{\circ}$ ), torna impossível, para a maioria dos destinatários, saber da existência de novas modalidades delituosas. Para quem desconhece e não tem possibilidade de se informar acerca da nova lei, é como se esta não existisse. Quantos aos tipos abertos, em que, pelo caráter vago da disposição incriminadora, ou pelo emprego de elementos normativos, deixa-se a juiz a missão de precisar os contornos e a aplicabilidade do preceito legislado, é por igual pequeno o alcance do princípio da reserva legal. Tipos como os de praticar atos destinados a provocar guerra subversiva ou de fazer propaganda subversiva (Dec. Lei $898 / 69$, arts. 25 e 45) podem se adaptar às mais variadas situações, de acordo com o paladar do juiz. Também é grande o arbítrio do julgador, quando tem de precisar, por exemplo, o que seja rixa, ato obceno ou desacato. O fenômeno não escapou à argúcia de Aníbal Bruno, que sabia muito bem como "pode sofrer a firmeza do Direito nos chamados tipos abertos, em que o enunciado da formulação típica deixa margem a incertezas na sua interpretação. Ou ainda como afeła a segurança da liberdade o emprego de fórmulas de demasiada amplitude que impõe limites mal definidos na enunciação dos fałos. É nesse mesmo sentido, que vem influir a tendência que se tem manifestado recentemente a introduzir na estrutura do tipo maior número de elementos normativos, de elementos cujo sentido não se deduz prontamente, mas tem de ser apreendido através de particular apreciação por parte do juiz e que trazem consigo, sobrefudo quando provém da linguagem comum, o germe da imprecisão. Isso não importa na pretensão de limitar o relativo arbítrio 
do juiz que se manifesta sobretudo na aplicação da pena, mas em defender a firmeza da definição do tipo, que é segurança da tiberdade. Nem significa, também, desconhecer que nem sempre é possível ou mesmo conveniente evitar o emprego de elementos normativos no tipo pelo uso de termos jurídicos ou mesmo da língua vulgar" (ob. cit., tomo IV, pág. 41).

Sendo difícil impedir, quer o surgimento de novas modalidades delituosas, quer a proliferação dos tipos abertos ou com elementos normativos, é indispensável assegurar, em tais casos, a liberdade, condicionando a punição à possibilidade que tenha tido o autor do ilícito típico de conhecer a antijuridicidade de sua conduta. E isto se obtém, ao erigir-se a culpabilidade, isto é, a censura pessoal, em firme pressuposto da pena. Ademais, estendendo-se a exigência da censurabilidade pessoal a todos os efeitos causados pela conduta do autor, impede-se seja o mesmo punido pelas conseqüências situadas além de sua vontade, desde que estas não the possam ser atribuíveis, sequer a título de negligência.

11. O diploma de 1969 pretendeu dar efetividade ao prinsípio do nula poena sine cuipa. Na Exposição de Motivos, lê-se que se "quiz ajustar a nossa legislação penal às exigências fundamentais de um Direisoo Penal da Culpa, que visa proscrever toda a forma de responsabilidade objetiva $\left(n .^{\circ} 3\right)$, bem como, que o princípio nullum crimen sine culpa é uma das constantes do Código e sua "significação exegética não deve ser esquecida" (n. 11). Só parcialmente, entretanto, o objetivo foi atingido.

Evitou-se a responsabilidade objetiva em relação aos crimes agravados ou quailficados pelo resultado. Pelos efeitos que agravamespecialmente as penas, só responderá o agente quando os houver causado, pelo menos culposamente (art. 19) e as sanções irão variar conforme o resultado mais grave seja imputável ao dolo ou à culpa do autor (art. 131, §§ $2 .^{\circ}$ e $3 .^{\circ}$ ).

Da mesma forma, não mais subsistirá responsabilidade sem culpa, na participação involuntária em crime mais grave. A punibilidade de qualquer dos concorrentes determinar-se-á segundo a sua própria culpabilidade (art. 35, § $1 .^{\circ}$ ). Assim, o mandante de lesões corporais não poderá ser responsabilizado pelo homicídio cometido por obra exclusiva do executor material, como sucede ante o diploma em vigor (C.P. 40, art. 48 parágrafo único). O critério doutrinário, de excluir a responsabilidade do mandante pelo crime mais grave, se não situado este na linha do normal desdobramento da ação, tem evitado, é certo, soluçães aberrantes (como a de punir o 
mandante do furto pelo estupro inesperadamente cometido pelo ladrão, encarregado apenas da subtração patrimonial). Mas tal entendimento, além de conflitar com o texto da lei, não impede uma desproporção entre a culpabilidade e a pena. É que na linha de normal desenvolvimento da ação situam-se todos os sucessos previsíveis da execução do crime (como a morte daquele a quem só se mandou espancar). Mas, esta previsibilidade, capaz de fundamentar uma responsabilidade a título de culpa, constitui justificativa para punição por dolo. Ora, o dolo, mais do que a previsibilidade, requer a vontade ou anuência em concorrer para o crime mais grave.

12. A responsabilidade sem culpa, contudo, permanece no novo Código, máxime em relação à ignorância da antijurididade por erro de direito, bem como na fórmula da inimputabilidade.

A boa fé do autor, por suposição de licitude da conduta, só o escusará se derivada de erro de fato (art. 21), ou seja, da suposição de situação de fato que tornaria a ação legítima. A mesma suposição de licitude, se derivada de ignorância ou errada compreensão da lei, somente atenuará a pena, e isto, desde que seja escusável. Ora, o erro escusável, é o erro invencível, pelo qual não se pode censurar o autor. Permitindo a nova lei a incidência da pena, ainda que atenuada, a quem não é passível de censura e, portanto, não é culpado, abre desnecessária brecha no princípio fundamental de que não há pena sem culpabilidade. A Aníbal Bruno já parecia que "quem inclui no dolo a consciência do ilícito, ou, como os finalistas, faz dessa consciência de agir de maneira contrária ao dever o núcleo da culpabîiidade, entendida como reprovabilidade perante a ordem de Direito, tem conseqüentenmente de admitir o êrro quanto à antijuridicidade do fato, desde que essencial e escusável, como penalmente relevante. Se falła ao agente a consciência da iliciłude, ou não existe dolo e, portanto, culpabilidade, ou, como para os finalistas, o dolo persiste, mas exclui-se a culpabilidade, e em todo caso o fato fica alheio à esfera da punição -" (ob. cit., tomo II, pág. 494). E o Seminário de Belo Horizonte, de Direito Penal e Processo Penal, acoThendo sugestão nossa, recomendou a revisão do art. 20, para permitir-se a total isenção de pena quando a suposição de licitude, ainda que derivada de erro de direito, seja plenamente escusável (ob. loc. cit.).

Sem repetir que a emoção e a paixão não excluem a responbilidade penal (C. P. 40, art. 24, I), o novo diploma basicamente reproduz a atual disposição acerca da inimputabilidade. Para ter efeitos eximentes, a incapacidade de entender o caráter criminoso do fato, ou determinar-se de acordo com este entendimento, tem 
de derivar de doença mental ou de desenvolvimento mental incompleto ou retardado (art. 31). Se a incapacidade volitiva ou intelectiva decorrer de transtorno mental transitório ou de grave perturbação da consciência, não haverá, em princípio, isenção de pena. Ora, estes estados, contemplados por outros códigos modernos como causas biológicas de inimputabilidade, são cientificamente aptos a anular o entendimento ou o auto-governo. Não os contemplando, - Código de 1969 cria, para tais siłuações, uma ficção de imputabilidade, permitindo, pois, a punição de quem, por incapacidade de entender ou de querer, não merece censura pessoal, nem é culpado. Esta violação ao nulla poena sine culpa, obrigará a melhor doutrina a forçar a inclusão das graves perturbações de consciência entre as doenças mentais, consoante já alertava Aníbal Bruno, comentando idêntica disposição do Código atual: "a fórmula demasiadamente restrita adotada pelo Código força a assimilar à całegoria da doença mental, do art, 22, ou da perturbação da saúde mental, do seu parágrafo único, certos esfados que as legislações modernas traduzem por expressões como "perturbação da consciência" (Código alemão, redação vigente, art. 51), "grave perturbação da consciência" (Código suíço, art. 10); "transtorno mental transił6rio" (Código espanhol, art. 8., n. $^{\circ} 1$ ), estados "crespusculares não patológicos ou fronteiriz̧os da patologia, como o sono normal, isto é, estados crepussulares que podem ocorrer no começo ou no fim do sono ou no sonambulismo ou na hipnose por sugestão, além de fatos de natureza mórbida, transitórios ou não, que comprometem o exercício normal das funções psíquicas, com profunda alteração da consciência e, por conseguinte, dos requisitos que a lei exige para o juízo de impửabilidade" (ob. cit., tomo II, pág. 513).

Melhor teria sido acatar a fórmula do Anteprojeto, com inclusão da grave anomalia psíquica entre as causas biológicas da inimputabilidade, ou a adoção do preceito do Código Penal Tipo para a América Latina, sugerido pelo próprio Ministro Nelson Hungria, preceito que alude à grave perturbação de consciência. Tal solução, aliás, foi recomendada pelo III Congresso Nacional de Direito Penal, Recife, 1970. (v. Alcides Munhoz Netto, A Culpabilidade no Novo Código, in Revista da Faculdade de Direito da U.F.Pr., ano 13, n. ${ }^{\circ}$ 13, pág. 143).

\section{CONSIDERAÇÕES FINAIS}

13. Do que foi exposto, verifica-se que a reforma brasileira ficou muito aquém do que se podia esperar, à vista das tendências contemporâneas em matéria punitiva. O diploma de 1969, apesar 
das emendas que the foram introduzidas, não descriminalizou, foi demasiadamente parcimonioso na despenalização e não logrou limitar, pela culpa, a responsabilidade penal.

Ao contrário do Código de 1940, que honrou a nossa cultura, o de 1969 apresenta-se em grande atraso para a sua época e em desacordo com o atual estágio do pensamento jurídico-penal brasileiro, inclusive com a doutrina magistralmente exposta pelo insigne mestre pernambucano, que Minas Gerais está a homenagear. Aníbal Bruno integrou, é certo, a segunda Comissão revisora do diploma ora em quarentena. Mas, as deficiências dessa legislação não lhe podem ser debitadas. Longe disso, por não the tolerar os vícios, ele externou o desejo de não vincular seu nome à imperfeita obra, afastando-se, depois, dos trabalhos de revisão (cfr. Heleno C. Fragoso, Subsídios Para a História do Novo Código Penal, in R.D.P. n. ${ }^{\circ} 3$, págs. 10/11).

As idéias liberais e as soluções tão precisas, quanto equilibradas, de Aníbal Bruno não foram incorporadas ao Novo Código. Contudo, aí estão atuais e palpitantes, como que a reclamar de todos os penalistas brasileiros um esforço ingente para a reforma da reforma das nossas instituições penais. 